\title{
COMPARISON OF THE ABILITY OF MATHEMATICAL REASONING OF SMK STUDENTS USING A METACOGNITIVE SKILL APPROACH THROUGH ADVANCE ORGANIZER LEARNING MODELS WITH A SAINTIFIC APPROACH THROUGH DISCOVERY LEARNING
}

\author{
Rosalina Rolina $^{1}$, Sri Aryani ${ }^{2}$, Erik Taufiqurrohman ${ }^{3}$ \\ ${ }^{1}$ IKIP Siliwangi, Cimahi \\ ${ }^{2}$ STKIP PGRI, Sukabumi \\ ${ }^{3}$ MTsN 1, Subang \\ ${ }^{1}$ maezarou@gmail.com, ${ }^{2}$ sriaryani@ @tkippgrisukabumi.ac.id, ${ }^{3}$ ekman_s1@yahoo.co.id
}

Received: Aug 6 ${ }^{\text {th }}, 2018 ;$ Accepted: Sep 14 ${ }^{\text {th }}, 2018$

\begin{abstract}
This research is motivated by the low level of mathematical reasoning ability students. This study aims to determine the comparison of mathematical reasoning abilities students between those who learn using the metacognitive skills approach through advance organizer and the scientific approach through discovery learning. The method is an experimental method with a pretest-posttest control group design involving two groups and random sampling. At the beginning and end of learning, the two classes are given a test. The population in this study were State Vocational High School students in Cimahi, while the sample consisted of two randomly selected classes. Obtained class XI TEK A which was given a metacognitive skill approach through advanced organizer and class XI TOI A is given a scientific approach through discovery learning. The instrument used was a 5-item mathematical reasoning ability test description, then the data mathematical reasoning students were analyzed with descriptive and inferential statistics using the help of SPSS 21 software. Based on the results of the study, it was concluded that the improvement of students' mathematical reasoning using skills the metacognitive skills approach through advance organizer is better than students who use a scientific approach through discovery learning.
\end{abstract}

Keywords: reasoning, metacognitive skills approach, advance organizer, scientific approach, discovery learning.

\begin{abstract}
Abstrak
Penelitian ini dilatarbelakangi oleh masih rendahnya kemampuan penalaran matematis siswa. Penelitian ini bertujuan untuk mengetahui perbandingan kemampuan penalaran matematis siswa antara yang pembelajarannya menggunakan pendekatan keterampilan metakognitif melalui model pembelajaran advance organizer dan pendekatan saintifik melalui discovery learning. Metode yang digunakan dalam penelitian ini adalah metode eksperimen dengan disain kelompok kontrol pretespostes yang melibatkan dua kelompok dan pengambilan sampel dilakukan secara acak kelas, pada awal dan akhir pembelajaran kedua kelas diberi tes. Populasi dalam penelitian ini adalah siswa SMK Negeri di kota Cimahi, sedangkan sampelnya terdiri dari dua kelas yang dipilih secara acak. Diperoleh kelas XI TEK A yang diberi pendekatan keterampilan metakognitif melalui model pembelajaran advance organizer dan kelas XI TOI A diberi pendekatan saintifik melalui discovery learning. Instrumen yang digunakan adalah bentuk tes uraian kemampuan penalaran matematis sebanyak 5 soal, kemudian data skor kemampuan penalaran matematis siswa tersebut dianalisis dengan statistik deskriptif dan inferensial menggunakan bantuan software SPSS 21. Berdasarkan hasil penelitian, disimpulkan bahwa peningkatan kemampuan penalaran matematis siswa yang menggunakan
\end{abstract}


234 Rolina, Aryani, and Taufiqurrohman, Comparison of the Ability of Mathematical Reasoning of SMK Students Using a Metacognitive Skill Approach Through Advance Organizer Learning Models with a Saintific Approach Through Discovery Learning

pendekatan keterampilan metakognitif melalui model pembelajaran advance organizer lebih baik dari siswa yang menggunakan pendekatan saintifik melalui discovery learning.

Kata Kunci: penalaran, pendekatan keterampilan metakognitif, advance organizer, pendekatan saintifik, discovery learning.

How to Cite: Rolina, R., Aryani, S., \& Taufiqurrohman, E. (2018). Comparison of the Ability of Mathematical Reasoning of SMK Students Using A Metacognitive Skill Approach Through Advance Organizer Learning with A Saintific Approach Through Discovery Learning. JIML, 1 (3), 233-238.

\section{INTRODUCTION}

Education is an attempt to humanize human beings. Education plays an important role in improving the quality of human resources. Mathematics education becomes one of the important elements in the formation of human thinking ability. Math lessons are expected to help students to think critically, logically, and systematically. Mathematics has the power as a tool in problem solving, communicating, and reasoning. Math information forms a solid network, and various topics can be well organized. For that required high skills that can be obtained and developed through quality mathematics education. Mathematical education that provides students with experience in shaping quantitative deductive reasoning abilities based on qualitative analysis using concepts and principles. Reasoning is also important because according to Setiawan \& Sari (2018) if students do not develop reasoning skills, then students will assume mathematics is only material that follows a series of procedures and imitates examples without knowing their meaning.

In the process of learning in the classroom, teachers have a very important role, especially in the transfer of knowledge and affection. The teacher adjusts the rate of information and interaction. The learning process is done by planting information in the minds of students.

The ability of students is directed to think how to achieve goals. Students are expected to be able to recognize conceptual thinking informally, to develop the thought of the observed case, to seek inductive arguments and analogous arguments by knowing concepts.

The main element of mathematics is deductive reasoning, which works with the assumption without observation. In addition, mathematics works on facts and phenomena to arrive at a certain estimate known as inductive reasoning. But that estimate must be verified. Students often have difficulty in developing this ability.

Bernard (2015) and Syaban (2008) said that reasoning is a thinking activity done in one way to draw conclusions. The ability of mathematical reasoning is a mental process and must be built continuously.

According Sumarmo (2014) reasoning ability includes:

1. Drawing logical conclusions.

2. Provide explanations using models, facts, traits and relationships.

3. Estimate answers and process solutions.

4. Using patterns and relationships to analyze mathematical situations, drawing analogies and generalizations.

5. Construct and test conjecture.

6. Gives an opponent example (counter examples).

7. Following the rules of inference; check the validity of arguments.

8. Compose valid arguments.

9. Establish direct proof, indirect proof, and induction. 
Sumarmo (2014) said that Broadly speaking reasoning can be classified into two types: inductive reasoning and deductive reasoning. Inductive reasoning is defined as a general or specific conclusion based on observed data. The value of truth in inductive reasoning can be either right or wrong. Deductive reasoning is a conclusion based on agreed rules. The value of truth in deductive reasoning is absolutely right or wrong and not both together. Deductive reasoning can be either low or high.

To improve students' reasoning abilities, one approach that can be used is the metacognitive skill approach. Metacognitive is an adjective of metacognition. The term metacognition comes from the word "metacognition" with the prefix "meta" and the word "cognition". Meta comes from Greek meaning "after" or "beyond" and cognition includes skills related to the thinking process.

Hacker (2003) in his book wrote that metacognition is an awareness experienced by itself as an activity in the environment, thus raising the height of the sense of ego that arises when doing activities of discussion, debate, listening, seeing and others, so stored intentionally and can be reappeared in the future. Metacognition refers to students' awareness of their abilities and the ability to understand, control and manipulate the cognitive processes they possess.

Metacognition emphasizes the consciousness of one's thinking about his own thought process. An awareness of what is known and what is unknown. The metacognitive approach strategy refers to ways to raise awareness of thought processes, so this approach is very well used to improve students' reasoning abilities. Thinking and reasoning is essentially the essence of mathematical activity.

This metacognitive skill approach can be supported by advance organizer learning model. The advanced organizer learning model is a way of learning to acquire new knowledge associated with existing knowledge, which means that each knowledge has a certain conceptual structure that forms the framework of the information processing system developed in that knowledge. This learning model has a purpose to strengthen the cognitive structure of adding new information memory.

The enactment of the 2013 curriculum that began to be implemented in some schools provides a new way in the learning process. This applies also to mathematics learning. This learning innovation is expected to improve students' mathematical ability. In this curriculum, the scientific approach is imperative. A scientific approach or more commonly called a scientific approach. Approach that refers to the scientific method. The scientific method basically views specific (unique) phenomena with specific and detailed studies to then formulate conclusions. Thus it is necessary to reason in the search (discovery). To be scientific, the method of inquiry should be based on the evidence of observable, empirical, and measurable objects with specific principles of reasoning.

Application of discovery learning will support a scientific approach. Scientific approach and discovery learning is an active learning approach and strategy, which is student-centered learning so that learners try to find their own various information needed. In learning not only active teachers or explaining continuously the material being studied but learners also play an active role to seek their own information to complement learning materials learned. The reasoning ability is one of the students' mathematical competencies related to the thinking process. Both approaches are used, will be able to improve the ability. But in this study will be compared how far the improvement of students' reasoning skills using metacognitive skills approach through advance organizer learning model by using the scientific approach through discovery learning. Both of these approaches emphasize the thinking process itself and are supported by an advanced organizer learning model that will strengthen its cognitive structure or with discovery learning that helps students improve and improve cognitive skills and processes.

\section{METHOD}

The method used in this research is the experimental method. This study involves two groups, namely the first experimental group and the second experimental group. All groups were given pretest and postes. 
236 Rolina, Aryani, and Taufiqurrohman, Comparison of the Ability of Mathematical Reasoning of SMK Students Using a Metacognitive Skill Approach Through Advance Organizer Learning Models with a Saintific Approach Through Discovery Learning

Thus the design patterns used in this study as follows :

A O X1 O

A O X 20

Ruseffendi (2005)

Information:

A: Random sampling by class

$\mathrm{X} 1$ : Learning using metacognitive skill approach through advance organizer learning model

$\mathrm{X} 2$ : Learning by using a scientific approach through discovery learning learning model

$\mathrm{O}$ : Pretes $=$ Postes (a question on pretest is the same as postes)

\section{RESULT AND DISCUSSION}

\section{Result}

Table 1. Description of Pretest and Posttest

\begin{tabular}{ccccccc}
\hline Statistics & \multicolumn{3}{c}{ Eksperiment I } & \multicolumn{3}{c}{ Eksperiment II } \\
\cline { 2 - 7 } & Pretest & Posttest & N Gain & Pretest & Posttest & N Gain \\
\hline $\begin{array}{c}\text { Numbers of } \\
\text { student }\end{array}$ & 30 & 30 & 30 & 32 & 32 & 32 \\
\hline $\begin{array}{c}\text { Minimum } \\
\text { Score }\end{array}$ & 4 & 11 & 0,1875 & 5 & 8 & 0,11 \\
\hline $\begin{array}{c}\text { Maximum } \\
\text { Score }\end{array}$ & 10 & 21 & 0,7857 & 11 & 21 & 0,78 \\
\hline $\begin{array}{c}\text { Average } \\
\text { Score }\end{array}$ & 7,733 & 15,67 & 0,46 & 7,16 & 14,25 & 0,42 \\
\hline $\begin{array}{c}\text { Percentage } \\
* \text { ) }\end{array}$ & $32,22 \%$ & $65,28 \%$ & $48,72 \%$ & $29,82 \%$ & $59,38 \%$ & $42,05 \%$ \\
\hline $\begin{array}{c}\text { Standard of } \\
\text { Deviation }\end{array}$ & 1,89 & 2,68 & 0,16 & 1,82 & 3,69 & 0,22 \\
\hline
\end{tabular}

*) Percentage $=$ comparison of mean scores to ideal maximum scores.

Based on description the pretest and posttest, the average score pretest is no difference. Both the average score posttest and N-Gain, mean there is difference in the ability of mathematical reasoning students who will use the metacognitive approach through advance organizer learning model by using the scientific approach through discovery learning.

Table 2. Output SPSS 21

\begin{tabular}{lllcc}
\hline & & \multicolumn{3}{c}{ Significance } \\
\cline { 3 - 5 } & & \multicolumn{2}{c}{ Experimental Class I } & \multicolumn{2}{c}{ Experimental Class } \\
II & \\
\hline \multirow{2}{*}{ Pretest } & Normality & 0,008 & & 0,000 \\
\cline { 2 - 5 } & Mann Whitney & & 0,113 & \\
\hline \multirow{3}{*}{ Posttest } & Normality & 0,187 & & 0,189 \\
\cline { 2 - 5 } & Homogeinity & & 0,171 & \\
\cline { 2 - 5 } N-Test & Normality & & 0,0455 & \\
\cline { 2 - 5 } N-Gain & Homogeinity & 0,200 & & 0,200 \\
\cline { 2 - 5 } & T-Test & & 0,191 & \\
\hline
\end{tabular}

Based on the pretest data processing result by using Kolmogorov Smirnov statistic test that the significance value is less than the specified significance, which means that the experimental class I and the experimental class II come from the non-distributed samples. So the test is continued with nonparametric Mann-Whitney test. From non-parametric test results Man-Whitney obtained significantly more significant than that determined, which means there is no difference in the ability of early 
mathematical reasoning students who will use the metacognitive approach through advance organizer learning model by using the scientific approach through discovery learning.

The result of data analysis of experimental class I and experiment class II using Kolmogorov-Smirnov statistic test which showed that experimental class I and experiment II class have significant value more than the significant value determined that mean both experiment class I and experiment class II normally distributed. In the homogeneity test of variance, the significance value obtained is more than the significance value determined so that there is no difference in variance of the two samples. Testing the mean difference with the t-test shows that the significance value is less than the specified significance. Appropriate criteria testing, significance less than 0.05 , this means the achievement of postes score of reasoning ability among students whose learning using metacognitive skills approach is better than students whose learning uses a scientific approach through discovery learning.

The result of analysis of experimental data of experimental class I and experiment class II using Kolmogorov-Smirnov statistic test which showed that experiment class I and experimental class II have significant value more than the significant value determined that mean both experiment class I and class experiment II is normally distributed. In the homogeneity test of variance, the significance value obtained is more than the significance value determined so that there is no difference in variance of the two samples. Testing the mean difference with the t-test shows that the significance value is more than the specified significance. As per the test criteria, the significance is more than 0.05 then Ho is accepted. This means there is no difference in the improvement of reasoning ability among students whose learning uses metacognitive skills approach with students whose learning uses a scientific approach through discovery learning.

The above statistical data describes the initial capabilities that are not different from the two experimental classes, after being treated differently in each class, a class with a metacognitive approach through the advanced organizer learning model and another class with a scientific approach through discovery learning, resulting in achievement different postes grades but an increase in reasoning ability that did not differ significantly. The achievement of postes grades in classes using metacognitive approach with advance organizer learning model is better than the class using scientific approach through discovery learning.

\section{Discussion}

Ruseffendi (2006) said that the approach is a way, the way, or the wisdom of the teacher or the student in achieving the teaching objectives in terms of how the teaching process or teaching material is, general, or specially managed. This indicates that every approach and learning strategy will affect the achievement of learning objectives, especially on the cognitive aspect.

Learning with a metacognitive skill approach is a cognition-raising effort and fosters confidence through questions and controls the thought process in building complete knowledge. The role of students is to master ideas and information. Meanwhile the advanced organizer learning model provides the concepts and principles to the students directly. The advanced organizer learning model aims to strengthen the cognitive structure of the students or their knowledge of a particular lesson and how to manage, clarify and maintain the knowledge well. So the metacognitive skill approach will be stronger if supported by advance organizer learning model.

Learning with a scientific approach is characterized by the exposition of the dimensions of observation, reasoning, discovery, validation, and explanation of a truth. This approach is known as $5 \mathrm{M}$ ie observing, asking, reasoning / associating, trying, and concluding. This approach is based on the scientific method. Discovery Learning as a learning strategy has the same principles as inquiry and Problem Solving. There is no principal difference in these three terms, in Discovery Learning more emphasis on finding a previously unknown concept or principle. 
238 Rolina, Aryani, and Taufiqurrohman, Comparison of the Ability of Mathematical Reasoning of SMK Students Using a Metacognitive Skill Approach Through Advance Organizer Learning Models with a Saintific Approach Through Discovery Learning

This reasoning ability is very focused on the ability to think logically. It is not surprising that the attainment of post grade grades using metacognitive approach through advanced organizers is better than the class using the scientific approach through discovery learning. While the improvement of reasoning ability of each experimental class does not differ significantly. The difference in the mean value of N Gain of the two classes is not far away, and statistically there is no difference in the increase in reasoning ability.

\section{CONCLUSION}

Based on the research that has been done about comparison of students' vocabulary reasoning ability using metacognitive approach through advance organizer learning model with scientific approach through discovery learning can be concluded that:

1. Achievement of students' vocational reasoning ability using metacognitive approach through advance organizer learning model is better than scientific approach through discovery learning.

2. Improving students' vocational reasoning ability using metacognitive approach through advance organizer learning model does not differ significantly with scientific approach through discovery learning

\section{REFERENCES}

Bernard, M. (2015). Meningkatkan Kemampuan Komunikasi dan Penalaran serta Disposisi Matematik Siswa SMA dengan Pendekatan Kontekstual melalui Game Adobe Flash CS 4.0. Infinity Jurnal Ilmiah Program Studi Matematika STKIP Siliwangi Bandung, 4(2).

Hacker. (2003). Metacognition: Fundaments, Applications and Trends. New York: Springer.

Ruseffendi, H. E. T. (2005). Dasar-Dasar Penelitian Pendidikan dan Bidang Non-Eksakta Lainnya. Bandung: Tarsito.

Ruseffendi, H. E. T. (2006). Pengantar kepada Membantu Guru Mengembangkan Kompetensinya Dalam Pengajaran Matematika.

Setiawan, W. dan, \& Sari, V. T. A. (2018). Pengembangan Bahan Ajar Konsep Diferensial Berbasis Konflik Kognitif. Jurnal Elemen, 4(2), 204. https://doi.org/10.29408/jel.v4i2.511

Sumarmo, U. (2014). Berpikir dan Disposisi Matematik serta Pembelajarannya. Bandung: Jurusan Pendidikan Matematika UPI.

Syaban, M. (2008). Menumbuhkembangkan Daya Matematis Siswa. Educare Jurnal Pendidikan Budaya, 5(2). 